УДК 631.3:621:695:553:973(043.3)

(СС.М. Хомич к.т.н., І.Є.Цизь, к.т.н., Л.Ю. Забродоцька к.т.н., Б.О. Рудика

Луцький національний технічний університет

А.В. Хомич к.т.н.

Любешівський технічний коледж Луцького національного технічного університету

\title{
ВИЗНАЧЕННЯ ПАРАМЕТРІВ ПОТОКУ ПОВІТРЯ ПРИ ДОБУВАННІ САПРОПЕЛЮ ПНЕВМОМЕХАНІЧНИМ ПРИСТРОЄМ
}

У статті представлено результати теоретичних досліджень визначення потужності повітряного потоку необхідного для приведення в дію фрези пневмомеханічного добувного пристрою, яка призначена для розрихлення нижніх $i$ середніх шарів сапропелю підвищеної в'язкості $i$ розрізанню рослинних включень

САПРОПЕЛЬ, ПОТІК ПОВІТРЯ, ОЗЕРО, ФРЕЗА, ЗАБІРНИЙ ПРИСТРІЙ, ПОТУЖНІСТЬ, ЕНЕРГІЯ, ШВИДКІСТЬ

Постановка проблеми. На сьогоднішній день питання добування органічного сапропелю для виготовлення добрив $\epsilon$ досить обговорюваним. Ним займаються як в Україні так і за кордоном [1...3].

Широкого поширення набуває пневматична технологія добування сапропелю вона зарекомендувала себе, як енергоощадна [4]. Для вдосконалення даної технології можна використовувати механічні машини в комбінованому компонуванні тобто пневмомеханічні.

Загалом поєднання даних технологій слугує підвищенню технологічної ефективності розробки середніх та нижніх шарів органічного сапропелю. Адже дані шари знаходяться в більш «злежаному» (підвищеної в'язкості і пониженої вологості) стані та потребують розрихлення в процесі добування. Також дані поклади можуть містити рослинні включення, які потрібно розрізати.

В свою чергу машини механічної дії не завжди можуть задовольнити виконання такої роботи на підвищених глибинах, вони мають складні механізми приводу і несуть більші енергозатрати.

Пропонований пневмомеханічний забірний пристрій [5], що входить до засобу для добування сапропелю не містить 
механічного механізму приводу, а лише фрезу, яка забезпечує розрихлення покладів та розрізання рослин. Привід фрези $є$ простим i забезпечується потоками стиснутого повітря, які виходять з сопел напірного повітропроводу.

Усунувши недоліки механічних добувних засобів запропонувавши пневмомеханічний, необхідно провести ряд обгрунтувань та досліджень для впровадження даної конструкції машини у виробництво та експлуатацію.

Таким чином дослідження спрямовані на удосконалення теоретичних обгрунтувань пневмомеханічних засобів для добування сапропелю, є актуальними.

Аналіз останніх досліджень і публікацій. Аналіз відомих способів добування сапропелів вказує на необхідність використання енергії стисненого повітря для розпушення (розрихлення) та добування покладів природної вологості. Найбільш перспективним 3 точки зору мінімізації та енергетичних затрат на отримання сапропелевої сировини для добрив $є$ пневматичні добувні засоби, що працюють 3 підводними та підземними розробками родовищ корисних копалин. Тому, запропонована нова конструкція пневмомеханічного забірного пристрою [5], що входить до складу засобу для добування сапропелю, призначеного для забезпечення сільського господарства якісною органічною сировиною для виробництва добрив являється альтернативною розробкою та потребує досліджень. Основні аспекти роботи даного засобу базуються на використанні енергії стисненого повітряного потоку, що взаємодіє 3 механічним розрихлювачем (фрезою) та разом являються робочими органами машин (рис. 1).

Запропонована конструкція забірного пристрою дозволяє добувати поклад середніх i нижніх шарів природної вологості підвищеної в'язкості. Оскільки конструкція є простою та забезпечує інтенсифікацію процесу то заощадження відбувається на власних енерговитратах. Суть роботи даного засобу заснована на формуванні двокомпонентного середовища шляхом самозаповнення забірної частини (змішувача) пристрою сапропелевою масою та примусової подачі стиснутого повітря. Останнє приводить в обертовий рух фрезу, що розрихлює поклади і бере участь у підніманні маси в вертикальному трубопроводі до надводної поверхні. 


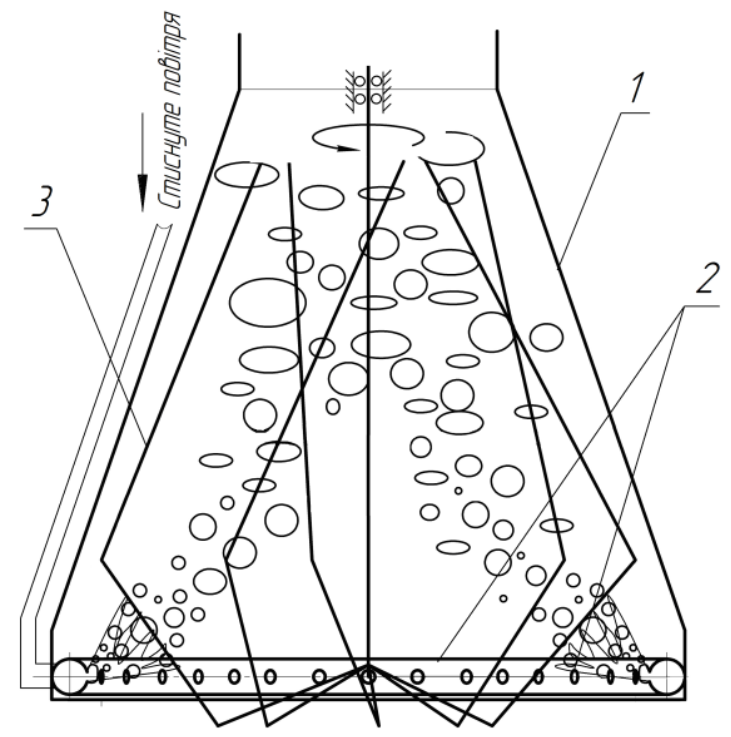

Рис. 1 - Схема конструкції та робочого процесу пневмомеханічного забірного пристрою: 1 - корпус (змішувач), 2 - напірний повітропровід з соплами, 3 - фреза

Для ефективного виконання технологічного процесу добування органічного сапропелю та виготовлення експериментальної установки для випробувань необхідно провести окремі теоретичні розрахунки та обгрунтування. Серед таких розрахунків слід приділити увагу визначенню максимальної потужності повітряного потоку, що затрачається на переміщення (приведення в обертальний рух) фрези для розрихленя покладів.

Метою дослідження $\epsilon$ обгрунтування параметрів повітряного потоку, як робочого органу пневмомеханічного добувного пристрою.

Результати дослідження. Під дією динамічного тиску потоку повітря на лопоті фрези пневмомеханічного забірного пристрою використовується енергія руху повітряного потоку. Для використання даної енергії необхідно, щоб лопоті фрези, на які діє сила набігаючого потоку, переміщалися, здійснюючи корисну роботу, яка полягає у розрихленні покладів сапропелю підвищеної в'язкості та спрямування їх до піднімального трубопроводу, також такий динамічний процес слугує формуванню двокомпонентного 
середовища за рахунок якого відбувається піднімання підводних покладів до надводної поверхні.

Для того, щоб раціонально використати цю енергію, необхідно, щоб набігаючий потік весь час діяв на лопоті, що поперемінно потрапляють в процесі руху під його дію.

Розглянемо простий випадок дії сили потоку повітря, що виходить 3 циліндричного сопла із швидкістю $v_{0}$ в середовище сапропелю і контактує з частиною лопоті фрези. Площа $S$, частини лопаті на яку діє потік стиснутого повітря, перпендикулярна напрямку потоку, переміщається із швидкістю $U$, яка співпадає в даний момент по напряму з швидкістю $v_{0}$ потоку, та на певній відстані від вихідного сопла має те ж значення що і площа потоку (рис. 2).

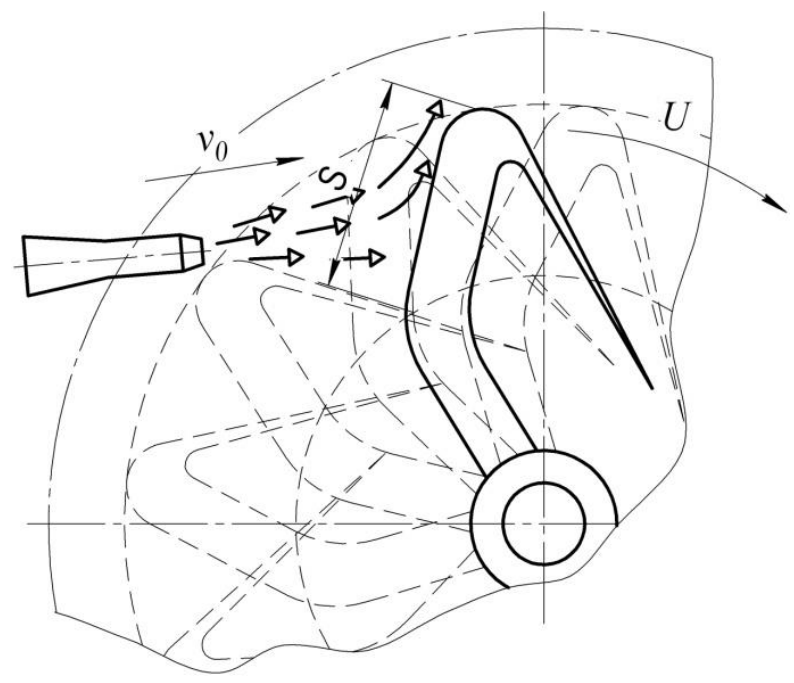

Рис. 2 - Розрахункова схема дії потоку повітря на лопать фрези

У такому випадку швидкість повітря яка діє на лопать фрези буде відносною:

$$
W=v_{o}-U
$$

За початкову швидкість повітряного потоку $v_{o}$ вважатимемо швидкість у найменшому його перерізі під час його виходу з сопла напірного повітропроводу. Дану швидкість для адіабатного процесу можна розрахувати за формулою [6]. 


$$
v_{0}=\sqrt{\frac{2 \cdot k \cdot P_{u}}{(k-1) \cdot \rho}\left[1-\left(\frac{P_{c}}{P_{H}}\right)^{\left(\frac{k-1}{k}\right)}\right]},
$$

де $k$ - показник адіабати, $k=1,4$;

$P_{н}$ - тиск повітря у напірному повітропроводі, Па;

$\rho=1,3$ при $20^{0} \mathrm{C}-$ густина повітря, кг/ $\mathrm{M}^{3}$;

$P_{c}$ - тиск у середовищі в яке виходить повітряний потік, Па.

У розглядуваному випадку повітряний потік виходить у середовище сапропелю, що знаходиться на глибині $\boldsymbol{H}$ та перебуває під тиском:

$$
P_{c}=P_{a m u}+\rho_{c} \cdot g \cdot H
$$

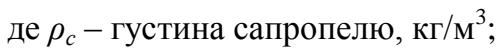

Тому залежність (2) набуде вигляду:

$$
v_{0}=\sqrt{\frac{2 \cdot k \cdot P_{u}}{(k-1) \cdot \rho}\left[1-\left(\frac{P_{a m u}+\rho \cdot g \cdot H}{P_{u}}\right)^{\left(\frac{k-1}{k}\right)}\right]} .
$$

Проте, швидкість повітря зростає зі зростанням різниці тисків $P_{c}$ і $P_{н}$ лише до тих пір поки дана швидкість не досягне межі швидкості звуку для даного середовища. Для повітря така різниця тисків визначається відношенням:

$$
\beta_{\kappa p}=P_{c} / P_{H}=0,528,
$$

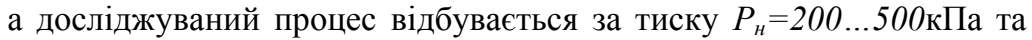
за $P_{c}=120 \ldots 160$ КПа. Тому швидкість у найменшому перерізі потоку слід розраховувати за формулою:

$$
v_{0}=v_{\kappa p}=\sqrt{\frac{2 \cdot k}{k-1} \cdot R \cdot T_{н}},
$$

де $T_{H}=293^{0} \mathrm{~K}-$ температура за якої знаходиться стиснуте повітря, що нагнітається, К;

$R-$ газова стала, Дж/( кг·К );

$k=1,4-$ показник адіабати.

Вважаючи, що потік безперервно діє на одну з лопатей, що поперемінно потрапляють на нього, можна визначити кількість руху всієї маси повітря, яка приводить в обертовий рух лопаті, за певний проміжок часу.

Масу повітря, що набігає на лопаті штовхаючи їх, за одиницю часу, можна виразити через рівну їй величину масової 
витрати повітря що виходить із сопла $m=\rho s v_{0}$, а кількість руху повітря що поступає на лопать на певній відстані становить:

$$
m W=\rho S v_{o}\left(v_{o}-U\right)
$$

де $S$ - площа перерізу тороїда, що описує частина лопаті на яку діє потік повітря при обертанні, приймається як площа лопаті, та площа контакту потоку повітря з лопаттю ${ }^{2}$ :

$$
S=\frac{m v_{0}}{\rho v_{0}\left(v_{0}-U\right)}
$$

Площа січення циліндричного сопла 3 якого входить повітря становить:

$$
s=\pi R^{2}
$$

3 врахуванням (6) та (9) отримаємо:

$$
m=\rho \pi R^{2} v_{0}
$$

де $\rho=1,3$ при $20^{\circ} \mathrm{C}$ - густина повітря.

$R^{2}$ - радіус сопла 3 якого виходить стиснуте повітря м

Оскільки сила динамічного тиску потоку на нерухому перешкоду визначається, як кількість рухомої маси потоку за одиницю часу, то у випадку рухомої лопаті фрези необхідно використовувати дійсну швидкість потоку, тобто можна скористатись значенням відносної швидкості $W$, тоді кількість руху повітря що поступає на лопать може бути визначена величиною $m W$ :

$$
F_{n}=m W=\rho S v_{o}\left(v_{o}-U\right)
$$

А кількість сапропелю яку лопать буде розрихлювати та переміщувати становитиме:

$$
Q=\rho_{c} S W
$$

де $\rho_{c}-$ густина сапропелю.

Потужність, що створюється потоком повітря, який виходить з одиничного сопла при набіганні на лопоті, визначається величиною:

$$
P=F_{n} U=\rho s v_{o}\left(U v_{o}-U^{2}\right)
$$

Максимальне значення потужності визначимо знайшовши похідну $\frac{d P}{d U}$ і прирівнявши ії до нуля:

$$
\frac{d P}{d U}=\frac{d\left(U v_{0}-U^{2}\right)}{d U}=v_{0}-2 U=0
$$

Звідси:

$$
U=\frac{v_{0}}{2},
$$


Отже, максимальна потужність буде отримана при русі лопатей 3 швидкістю, рівній половині швидкості набігаючого потоку. I виражається формулою:

$$
P_{\max }=\rho S\left(v_{0}^{2} U-v_{0} U^{2}\right)=\rho S\left(\frac{v_{0}^{3}}{2}-\frac{v_{0}^{3}}{4}\right)=\rho S \frac{v_{0}^{3}}{4}
$$

Якщо не враховувати конструктивні особливості фрези згідно рис. 1 i вважати, що вона $є$ плоскими циліндричними пластинам, то з даної формули можна зробити висновок, що при допомозі такої фрези для розрихлення поклав сапропелю можна використовувати тільки половину кінетичної енергії потоку, що поступає на лопать. А оскільки кількість сопел напірного повітропроводу $є n$ то максимальна потужність на переміщення фрези буде прямо пропорційною їх кількості.

Висновоки. Отримані результати показують, що степінь використання енергії для переміщення фрези, яку створює потік $є$ неповною, але з врахуванням характеристик сапропелю та робочого процесу засобу для його добування, можна погодитись, що інша половина енергії повітряного потоку буде використовуватись на подолання опору середовища та для утворення повітряного гвинта в середовищі сапропелю, а в подальшому для піднімання його у циліндричному вертикальному трубопроводі до надводної поверхні.

Використання пневмомеханічного забірного пристрою для добування сапропелю, як альтернативного, та методів розрахунку його параметрів дасть можливість зменшити енергозатрати на добування сапропелю в порівнянні з механічними засобами.

\section{Література}

1. Технические характеристики и принципы работы ПКН [Электронной ресурс]. - Режим доступу:http://www.pneuma.lv

2. Технология добычи и переработки сапропеля [Електронний peсурс]. Режим доступу: $\quad$ http://z.mz.ua/tekhnologiiprimeneniya/tekhnologiya-dobychi-i-pererabotki-sapropelya

3. Дослідження добування озерного сапропелю з-під шару води та його використання під час виробництва органічних добрив [Електронний ресурс]. - Режим доступу: http://www.agrmash.info/zb/29/23.pdf

4. Хомич С.M. Порівняльна ефективність пневматичних пристроїв для добування озерних сапропелів / С.М. Хомич, I.Є. Цизь // Матеріали IX-ої міжнародної наукової конференції «Проблеми конструювання, виробництва та експлуатації сільськогосподарської техніки», вип. 1. - Кіровоград, 2013. - С. 50 52. 
5. Пат. 99506 України, МПК Е02F 3/08. Забірний пристрій / заявник і патентовласник Хомич С.М., Цизь І.С., Трохимчук Р.М. Луцький НТУ. - №u201413475; заявл. 15.12.2014; опубл. 10.06.2015, Бюл. №11.

6 Христианович С.А. Прикладная газовая динамика / Христианович С.А., Гальперин В.Г., Миллионщиков М.Д., Симонов Л.А. - М., 1948. - С. 148. 